Western North American Naturalist 67(3), (C) 2007, pp. 439-451

\title{
AQUATIC VERTEBRATE ASSEMBLAGES OF THE UPPER CLEAR CREEK WATERSHED, CALIFORNIA
}

\author{
Larry R. Brown ${ }^{1,2}$ and Jason T. May ${ }^{1}$
}

\begin{abstract}
AвsтRACT.-We sampled streams in the Upper Clear Creek Watershed in northwestern California in fall 2004 and fall 2005 to document assemblages of aquatic vertebrates and to provide resource managers with information on the importance of these assemblages in terms of regional biodiversity. We used single-pass backpack electrofishing to sample 15 sites in fall 2004 and the same 15 sites plus 4 new sites in fall 2005 . We captured 10 fish taxa and 2 species of larval amphibians. Seven of the fish taxa were native species. Of the exotic species, only brook trout (Salvelinus fontinalis) occurred at more than 1 site. Ordinations by nonmetric multidimensional scaling indicated a gradient from sites with rainbow trout (Oncorhynchus mykiss), Pacific giant salamander (Dicamptodon tenebrosus), and tailed frog (Ascaphus truei) to sites dominated by riffle sculpin (Cottus gulosus), California roach (Hesperoleucas symmetricus), and Sacramento sucker (Catostomus occidentalis). The gradient in species composition was associated with changes in elevation, gradient, discharge, and substrate. The Upper Clear Creek Watershed represents a unique area of overlap between the North Coast California amphibian fauna and the Central Valley fish fauna with a notable paucity of exotic fishes and amphibians. Preservation of the integrity of native aquatic assemblages is an important goal for aquatic resource management in the region; our results provide a critcial baseline to gauge future management actions.
\end{abstract}

Key words: Clear Creek, California, Whiskeytown National Recreation Area, biodiversity, fish communities, amphibians, Klamath-Siskiyou Ecoregion.

Native fish and amphibian assemblages are presently being altered worldwide by a variety of human activities (Williams et al. 1989, Bruton 1995, Lever 1996, Beebee and Griffiths 2005, Gopal 2005). In California, native fish assemblages have been greatly altered since the mid-1800s by a combination of factors including habitat alteration, alteration of flow regimes, and invasions of exotic species (Moyle 2002, Brown and Moyle 2005). The introduction of exotic fishes has led to the overall homogenization of the California fish fauna (Marchetti et al. 2001); however, the success of exotic fishes and the degree of homogenization in particular watersheds are dependent on a number of factors, including watershed development, number of dams, reservoir density, aqueduct density, elevation, and precipitation (Marchetti et al. 2001, Marchetti et al. 2006). Native amphibian assemblages have been affected by similar factors (Jennings and Hayes 1994), and predation by introduced fishes and amphibians has been identified as particularly important (Knapp and Matthews 2000, Matthews et al. 2001, Knapp 2005, Welsh et al. 2006).
In this paper, we document the assemblages of aquatic vertebrates, including fishes and amphibians, in the streams of the Upper Clear Creek Watershed, which is partially contained within Whiskeytown National Recreation Area, located in northern California (Fig. 1). The primary objective of the study was to document the aquatic vertebrate assemblages supported by the streams in the area and to assess the significance of the assemblages to biodiversity within the region. We also used habitat variables to document stream habitat characteristics in the area and the relations of the aquatic vertebrate assemblages. This critical information ensures that local resource managers can make informed decisions regarding aquatic resources.

\section{Study Area}

The study area is located in northwestern California in the Upper Clear Creek Watershed, mainly within Whiskeytown National Recreation Area (Fig. 1). The watershed extends across numerous private and public properties, including lands managed by the National 


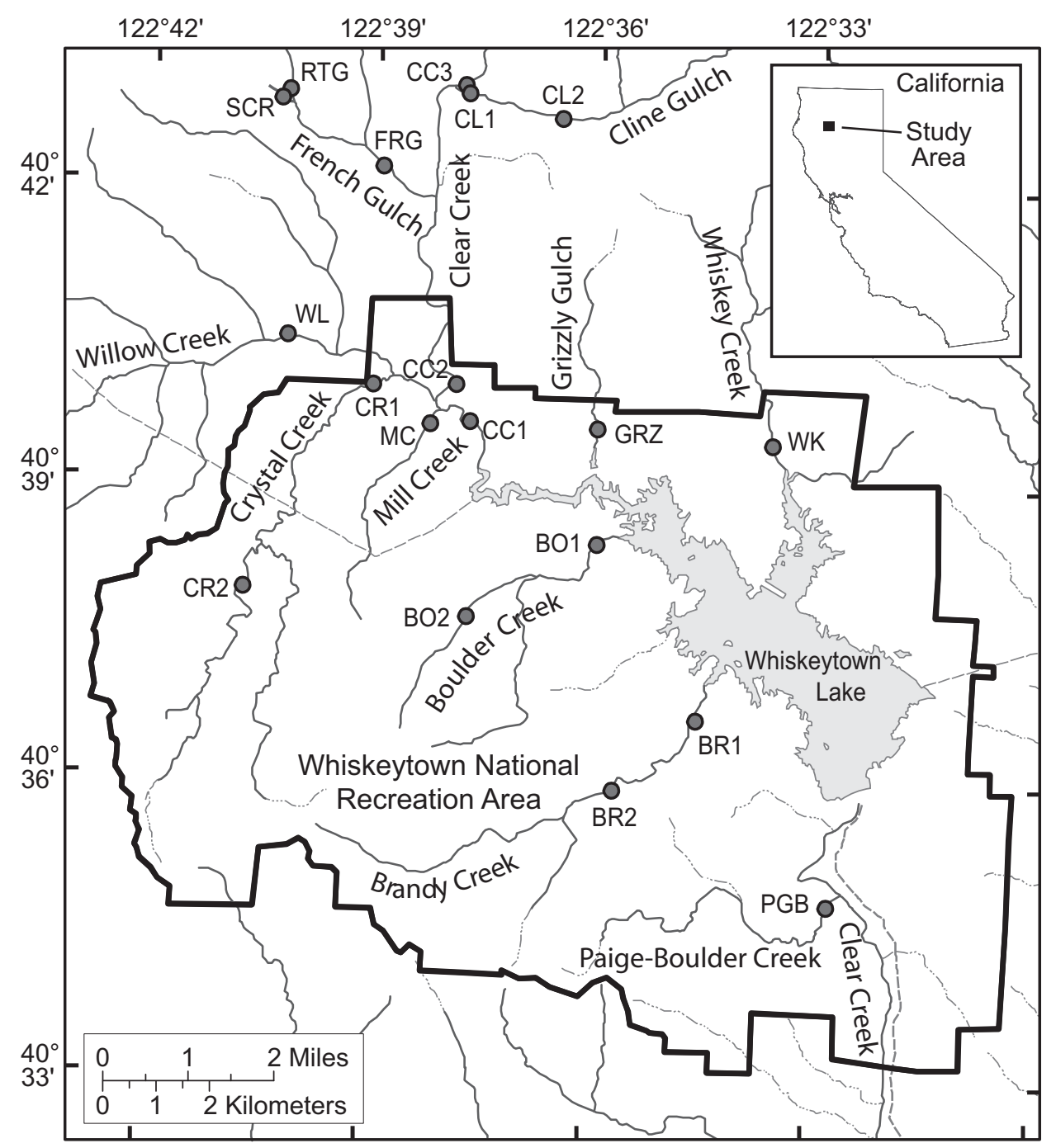

Fig. 1. Location of study sites within the Upper Clear Creek Watershed, California.

Park Service, the Bureau of Land Management, and the USDA Forest Service.

Whiskeytown National Recreation Area is located at the convergence of 3 physiographic provinces: the Cascade Range, the Coast Range, and the Sacramento Valley. The study area has a Mediterranean climate with hot $\left(>38^{\circ} \mathrm{C}\right)$, dry summers and cool $\left(<0^{\circ} \mathrm{C}\right)$ winters with moderate rainfall. Mean annual rainfall in the area is approximately $1500 \mathrm{~mm}$. The study area lies within the Klamath-Siskiyou Ecoregion, an area of significant biodiversity, especially for terrestrial plants (DellaSala et al. 1999). The plant communities in this region can be grouped into 7 general terrestrial plant communities (Biek 1988, Sawyer and KeelerWolf 1995), which intergrade in complex patterns, resulting in many distinctive species assemblages and few distinct boundaries between communities. The complex distribution of the plant communities reflects the region's broad range of elevation, the rugged topography, the diverse soil types, and the history of natural and human disturbance. The region has a moderately rich herptofauna of 38 species because the region represents an area of overlap between northern and southern taxa and because the complex and patchy nature of the 
habitats can support a wide range of species (Bury and Pearl 1999). In the context of fish zoogeography, the study area lies within the Central Valley subprovince of the larger Sacramento-San Joaquin Province (Moyle 2002). The Central Valley fish fauna includes 28 native species, many of them endemic to California, and 40 exotic species (Moyle 2002).

There is a long history of human disturbance in the area. The Clear Creek watershed was historically the scene of extensive mining operations and timber harvests. Mining activities left numerous dredge-tailing piles, pits, tunnels, roads, and acid drainage. Runoff from abandoned mine lands has resulted in elevated levels of metals in the stream sediments (Moore 2002). Timber harvests have left approximately $500 \mathrm{~km}$ of poorly constructed timber haul roads and skid roads. Sedimentation generated from surface erosion and landslides is a concern in the Clear Creek watershed. The high-elevation headwaters of Clear Creek transport large quantities of fine-grained sediment from old logging and mining roads into Lower Clear Creek. Fine-grained sediment is a particular concern downstream of Whiskeytown Reservoir because it can degrade anadromous fish habitat.

\section{MethodS}

We sampled 15 sites in fall 2004 (Table 1, Fig. 1). We sampled the same 15 sites plus an additional 4 sites in fall 2005. Sites on the main stem of Clear Creek were $400 \mathrm{~m}$ long (Table 1). Sites on the smaller tributary streams were $150 \mathrm{~m}$ long, except on several very small tributaries, where sites were $100 \mathrm{~m}$ long.

We sampled fishes and larval amphibians with single-pass backpack electrofishing with a Smith-Root Type XII electrofisher. We measured total length of fishes and tadpoles of tailed frogs (Ascaphus truei) to the nearest millimeter. We measured snout-vent length of Pacific giant salamander larvae (Dicamptodon tenebrosus) to the nearest millimeter. Adult amphibians were noted visually but were not collected. We weighed at least 30 individuals of each species to the nearest $0.1 \mathrm{~g}$ on an electronic balance, except for very small individuals, which were sometimes weighed in batches. The fishes weighed at each site covered the available size range at that site. We used these data to derive length-weight relationships for each site so that weights could be assigned to unweighed individuals.

We characterized habitat for each site according to Fitzpatrick et al. (1998). In short, we characterized habitat at each of 11 equally spaced transects oriented perpendicular to stream flow. At each transect we measured wetted channel width with a fiberglass tape. We measured the arc of open sky $\left(0^{\circ}-180^{\circ}\right)$ above the middle of the stream using a clinometer. We measured streamside shading using a densiometer at the left and right banks. At 3 points on each transect we measured stream depth ( $\mathrm{m}$, calibrated wading rod) and water velocity $\left(\mathrm{m} \cdot \mathrm{s}^{-1}\right.$, electronic flow meter), and characterized the dominant substrate size (see Table 1 for substrate categories). Substrate was characterized visually with the aid of a ruler. We measured stream gradient using a surveying level and rod. We determined percentages of riffle, run, and pool in the reach. Mean elevation of each stream reach was determined from topographical maps.

To address our primary objective of documenting aquatic vertebrate assemblages, we assessed patterns in aquatic vertebrate species composition using nonmetric multidimensional scaling (NMS; Kruskal 1964a, 1964b, Mather 1976). NMS is currently gaining favor in ecology over previous methods of characterizing assemblage structure such as correspondence analysis and detrended correspondence analysis (Clarke and Warwick 2001, McCune and Grace 2002). NMS is an ordination technique that summarizes (reduces the dimensionality of) a matrix of among-sample similarity coefficients. NMS is similar in concept to other ordination techniques, such as principal components analysis or correspondence analysis. Proportional abundances of species by number and by biomass were examined using normal probablility plots, and data were subsequently arcsine square-root transformed to improve normality and homogeneity of variance. BrayCurtis similarities were used as the similarity coefficient. The "fit" of the ordination was assessed by the stress value. Conceptually, stress compares original similarities calculated between samples from the full data matrix with similarities calculated between samples in the lower-dimension ordination space. Stress of $<0.20$ indicates that the lower-dimension ordination successfully reproduces the patterns present in the higher-dimension ordination 


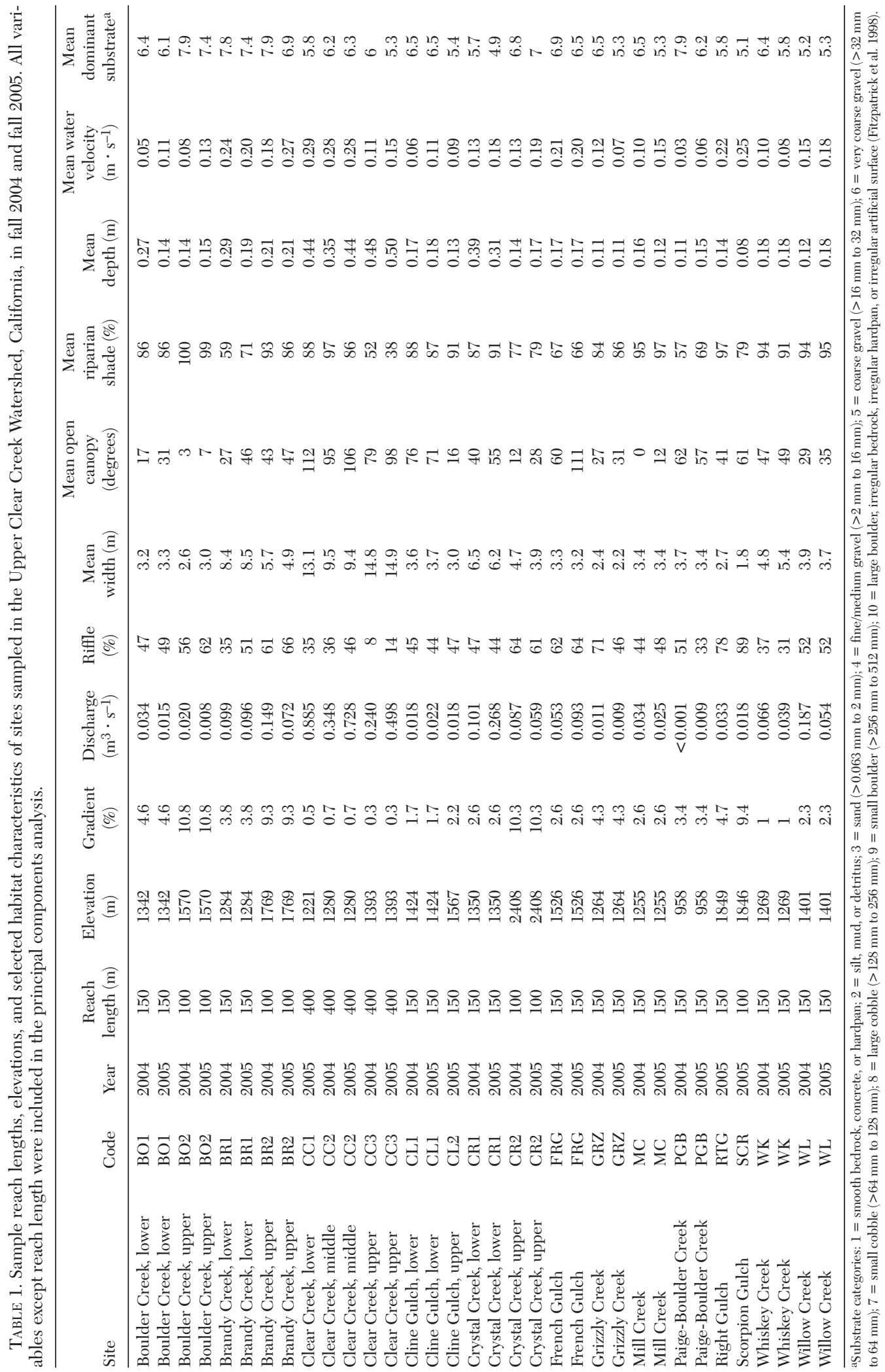


TABLE 2. Frequency of occurrence (percentage of sites where a species was found; $n=34)$, percent number $(n=$ 4938), and percent biomass $(n=44,143 \mathrm{~g}$ ) for species captured by electrofishing in the Upper Clear Creek Watershed, California, in fall 2004 and fall 2005. Exotic species are indicated by an asterisk.

\begin{tabular}{|c|c|c|c|c|}
\hline Common name & Scientific name & $\begin{array}{c}\text { Frequency of } \\
\text { occurrence }(\%)\end{array}$ & $\begin{array}{l}\text { Number } \\
(\%)\end{array}$ & $\begin{array}{c}\text { Biomass } \\
(\%)\end{array}$ \\
\hline Rainbow trout & Oncorhynchus mykiss & 94 & 14 & 30 \\
\hline Riffle sculpin & Cottus gulosus & 79 & 62 & 41 \\
\hline Pacific giant salamander & Dicamptodon tenebrosus & 65 & 3 & 10 \\
\hline Sacramento sucker & Catostomus occidentalis & 41 & 3 & 4 \\
\hline California roach & Hesperoleucas symmetricus & 38 & 12 & 3 \\
\hline Brook trout* & Salvelinus fontinalis & 21 & $<1$ & 10 \\
\hline Tailed frog (tadpole) & Ascaphus truei & 18 & 1 & $<1$ \\
\hline Sacramento pikeminnow & Ptychocheilus grandis & 12 & 2 & $<1$ \\
\hline Hardhead & Mylopharodon conocephalus & 9 & 2 & $<1$ \\
\hline Largemouth bass* & Micropterus salmoides & 3 & $<1$ & $<1$ \\
\hline Green sunfish* & Lepomis cyanellus & 3 & $<1$ & $<1$ \\
\hline Lamprey & Lampetra sp. & 3 & $<1$ & $<1$ \\
\hline
\end{tabular}

space (Clarke and Warwick 2001). To aid in the interpretation of ordination axes, we calculated Spearman rank correlations between ordination scores and the original species percentage data.

We used principal components analysis (PCA) to identify environmental gradients among our sites that could potentially affect the distribution of organisms. The analysis calculates independent (orthogonal) PCA axes that represent combinations of the original variables. Thus, each PCA axis represents an independent habitat gradient. We included the mean and the coefficient of variation in the data analysis for variables with multiple measurements per site (Table 1). We examined normal probability plots of the data and transformed data as needed to improve normality and homogeneity of variance. Only PCA axes with eigenvalues $>1$ were retained for interpretation (Kaiser-Guttman criterion; Legendre and Legendre 1998).

We used the BV-STEP procedure in PRIMER (Clarke and Warwick 2001) to address the objective of identifying relations of aquatic vertebrate assemblages with habitat variables. This procedure relates the patterns in assemblage composition summarized by NMS to an optimum set of environmental variables. This multivariate permutation test works by comparing a matrix of Euclidean distances calculated from environmental measurements with the species' Bray-Curtis similarity matrix. A high correlation indicates a strong association of the species assemblage with the measured environmental variables.
This analysis proceeds in a stepwise manner and tests combinations of environmental variables to determine the best model. We conducted 100 permutations of the procedure and present the most frequently selected models.

\section{Results}

We captured 10 fish taxa and 2 species of larval amphibians (Table 2). Rainbow trout appeared in the highest number of samples (32 of 34) and occurred in every stream (Table 3). Riffle sculpin was the most abundant species in terms of both number and biomass (Table 2) and was absent from only Scorpion Gulch (Table 3). We did not capture adult lampreys, so we could not identify the lampreys to species because adult characters are required for species identification. Ammocoetes (larval lampreys) were collected at only the lowermost Clear Creek site. Of the fish taxa, only 3 were exotic species. Of the exotic fishes, only brook trout occurred in more than 1 sample. Brook trout made up $<1 \%$ of the total number of fish that we captured; however, brook trout composed a significant portion of the biomass (10\%) because all the captured individuals were large adults. Brook trout were collected at only the downstream sites in Boulder, Brandy, Crystal, and Mill creeks (Table 3). We captured no exotic amphibian larvae. We did capture 1 adult of the exotic bullfrog Rana catesbeiana at the Whiskey Creek, in addition to exotic green sunfish and largemouth bass (Table 3).

Pacific giant salamander larvae were not captured in the mainstem Clear Creek (Table 


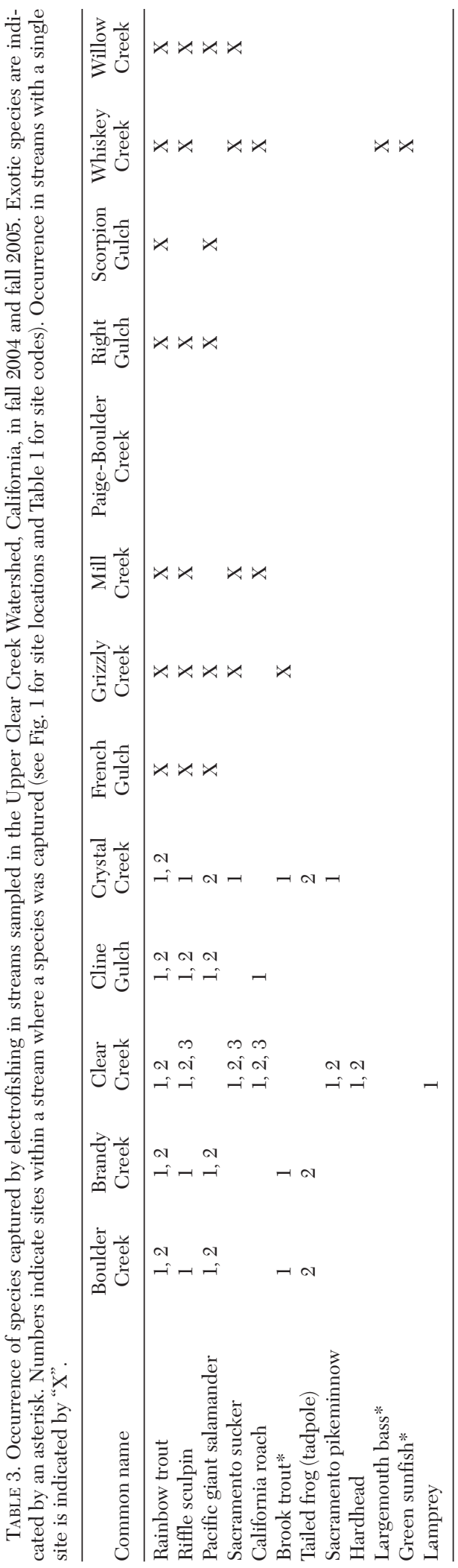

3); however, a single individual was captured in 2006 as part of another study (J.T. May unpublished data), which indicates that they may have been present in low numbers. Tailed frog tadpoles were observed at only the upper sites on Brandy, Boulder, and Crystal creeks, where riffle sculpin was absent (Table 3). We observed adult tailed frogs at the upstream sites on the Brandy and Boulder creeks. Adult foothill yellow-legged frogs (Rana boylii) were observed in Cline Gulch, Grizzly Gulch, Scorpion Gulch, Mill Creek, Paige-Boulder Creek, and Willow Creek.

Two-dimensional ordinations gave low stress values for both percent number (stress $=0.07$ ) and percent biomass (stress $=0.12$ ). The ordination based on numerical percent abundances identified 3 large groups based on $60 \%$ similarity among samples (Fig. 2). The correlations of individual species with the ordination axes indicated that the primary gradient was from sites dominated by rainbow trout, tailed frog tadpoles, and Pacific giant salamander larvae to sites dominated by riffle sculpin, California roach, and Sacramento sucker. The secondary gradient was related to percent abundance of California roach. The Middle Clear Creek samples were identified as slightly different from the group containing the other Clear Creek samples, and the 2004 Paige-Boulder Creek sample was identified as very different from the other groups. The group that included the upper Brandy, Boulder, and Crystal Creek samples was unique because of the absence of riffle sculpin and the presence of tailed frog. The middle group was characterized by relatively similar percent abundances of riffle sculpin, rainbow trout, and Pacific giant salamander. The large group, which included most of the rest of the samples, was characterized by the high percent abundance of riffle sculpin compared to other species. The Paige-Boulder Creek 2004 sample was unusual compared to the other samples because of the high percent abundance of California roach (92\%).

The ordination of data on percent biomass identified 6 groups of sites at $60 \%$ similarity (Fig. 3). The pattern of species correlations was similar to the percent abundance ordination, except that the 2 nd axis was related to percent biomass of brook trout in addition to that of California roach. The group of upstream sites was identical to the group identified in the percent abundance analysis because of the 


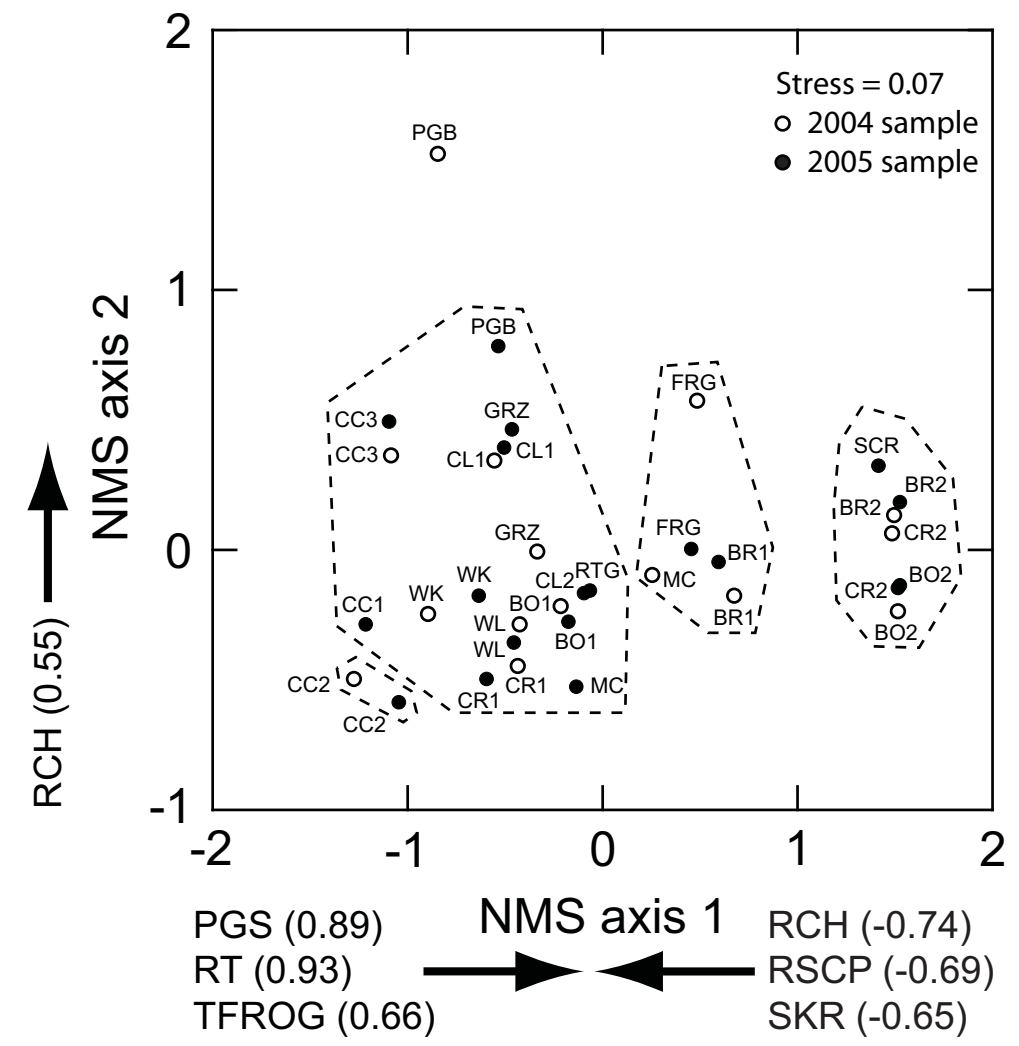

Fig. 2. Ordination scores from nonmetric multidimensional scaling (NMS) analysis of aquatic vertebrate percent abundances from Upper Clear Creek Watershed, California, in fall 2004 and fall 2005. Dashed polygons contain samples that are $\geq 60 \%$ similar to each other. Numbers in parentheses are statistically significant $(P<0.05)$ Spearman rank correlations between the NMS axis scores (derived from analysis of all species) and percent abundances of individual species. Only species with $|r|>0.5$ are shown. Arrows indicate the direction of increasing species abundance. PGS $=$ Pacific giant salamander, $\mathrm{RCH}=$ California roach, $\mathrm{RSCP}=$ riffle sculpin, $\mathrm{RT}=$ rainbow trout, $\mathrm{SKR}=$ Sacramento sucker, and TFROG $=$ tailed frog. See Table 1 for site codes.

presence of tailed frog tadpoles and the absence of riffle sculpin. Similarly, the 2004 PaigeBoulder Creek sample was again identified as unique because of the dominance of California roach $(75 \%)$. The Clear Creek and Whiskey Creek samples were characterized by the dominance of riffle sculpin. The group that included the samples from lower Boulder Creek (2005), lower Crystal Creek (2004 and 2005), Mill Creek (2004), and Willow Creek (2005) was characterized by the presence of adult brook trout. The remaining 2 groups were differentiated by different percent biomasses of rainbow trout, riffle sculpin, and Pacific giant salamander larvae. The group which included the 2004 samples from lower Brandy Creek, lower Boulder Creek, Grizzly Gulch, and French Gulch had relatively even percent biomasses of these 3 species. The other group of samples was more dominated by rainbow trout.

Principal components analysis identified 5 PCA axes with eigenvalues greater than 1 that explained $82 \%$ of the variance in the habitat data. The majority of variance (53\%) could be attributed to 2 major gradients in habitat condition (Fig. 4). The 1st gradient was associated with stream size and the 2 nd with stream elevation. The 3rd PCA axis explained $12 \%$ of the variance and was mainly associated with substrate size and CV of substrate size. The 4th PCA axis explained $10 \%$ of the variance and was related to $\mathrm{CV}$ of substrate size, $\mathrm{CV}$ of riparian shade, and $\mathrm{CV}$ of stream width. The 5th PCA axis explained 8\% of the variance and was related to elevation and CV of depth. 


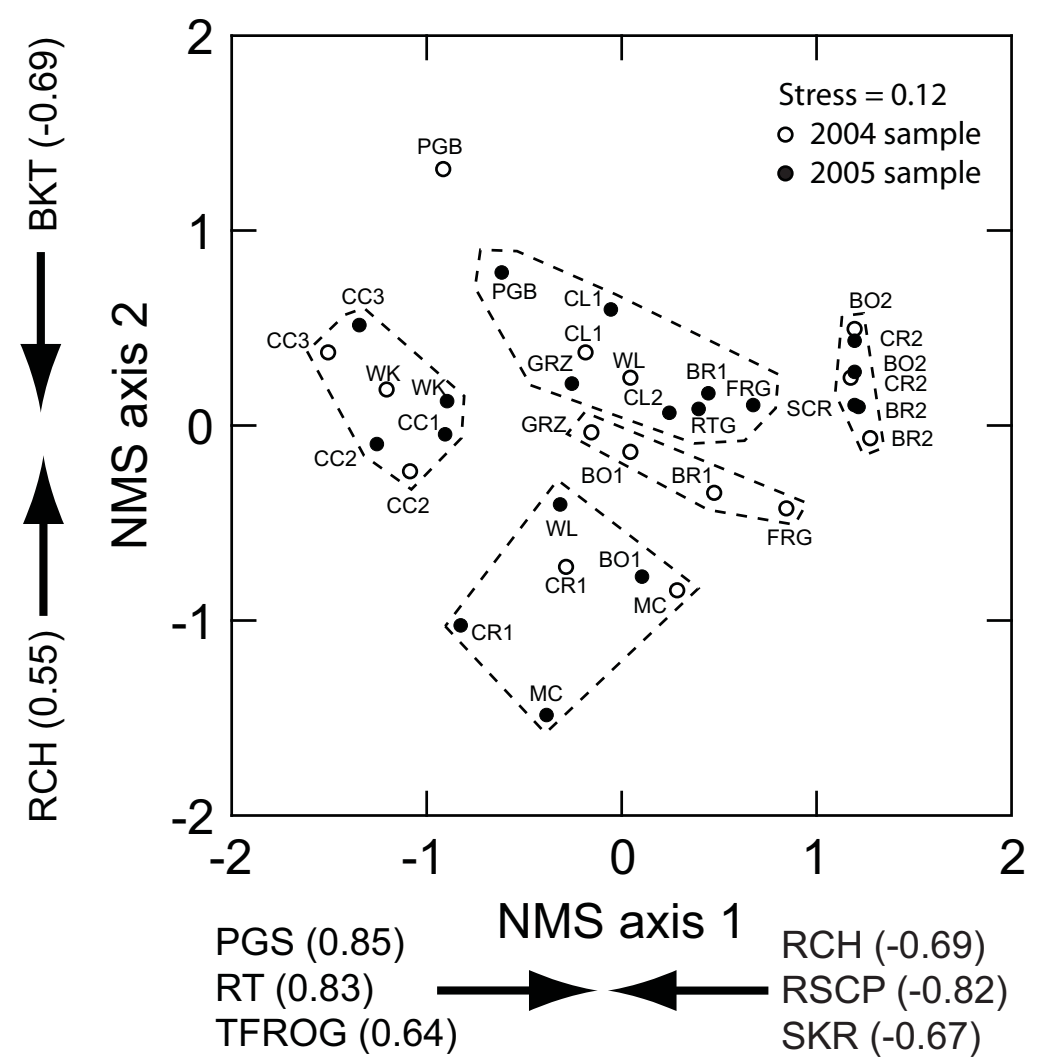

Fig. 3. Ordination scores from nonmetric multidimensional scaling (NMS) analysis of aquatic vertebrate percent biomass from Upper Clear Creek Watershed, California, in fall 2004 and fall 2005. Dashed polygons contain samples that are $\geq 60 \%$ similar to each other. Numbers in parentheses are statistically significant $(P<0.05)$ Spearman rank correlations between the NMS axis scores (derived from analysis of all species) and percent biomass of individual species. Only species with $|r|>0.5$ are shown. Arrows indicate the direction of increasing species abundance. BKT $=$ brook trout, PGS $=$ Pacific giant salamander, $\mathrm{RCH}=$ California roach, $\mathrm{RSCP}=$ riffle sculpin, $\mathrm{RT}=$ rainbow trout, $\mathrm{SKR}=$ Sacramento sucker, and TFROG $=$ tailed frog. See Table 1 for site codes.

The BV-STEP procedure indicated that the variability in the percent abundance data could be explained with a small subset of the habitat variables. A model including elevation, gradient, discharge, and mean dominant substrate was the best model in 81 of 100 permutations. The Spearman correlation of this set of habitat variables with the species data was $r=$ 0.68 . For the percent biomass data, a model including only gradient and discharge gave a high correlation with the species data $(r=$ $0.56)$ and was the best fit in 49 of 100 permutations. The 2nd-best model $(r=0.57)$ was the best fit in 38 of 100 permutations and included elevation, gradient, discharge, and mean dominant substrate (similar to the model for percent abundance), plus percent riffle. Gradient and discharge are related to the stream size gradient represented by PCA axis 1 (Fig. 4). Elevation is related to the stream elevation gradient represented by PCA axis 2 .

\section{Discussion}

The streams of the Upper Clear Creek Watershed provide habitat for a variety of aquatic vertebrate species. Gradients in habitat conditions, particularly in elevation, gradient, discharge, and substrate, appear to be important in determining the distribution of species in the area and the resulting aquatic vertebrate assemblages. Assemblages varied from a relatively simple combination of rainbow trout, Pacific giant salamander, and tailed frog typical of high-elevation, high-gradient headwater stream sites to combinations of riffle sculpin, 


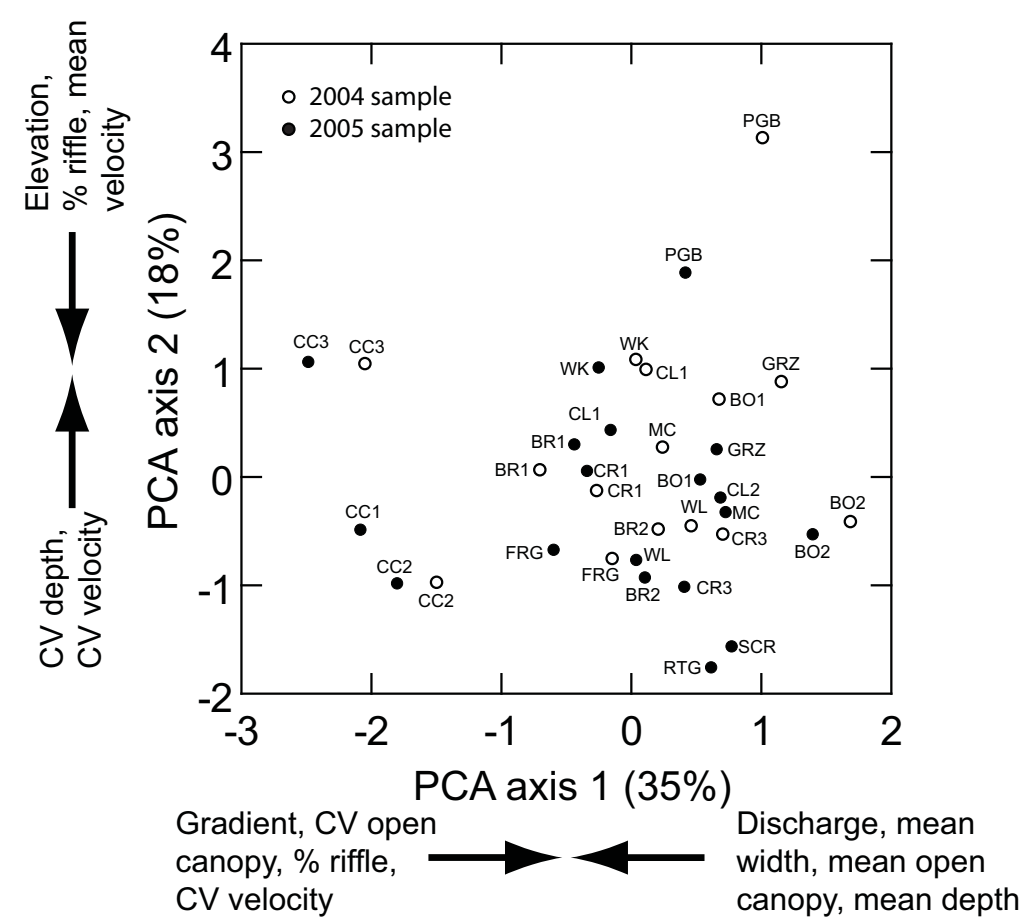

Fig. 4. Site scores on the first 2 axes of a principal components analysis (PCA) of habitat data collected from Upper Clear Creek Watershed, California, in fall 2004 and fall 2005. Percentages in parentheses are the amount of variance explained by each PCA axis. Arrows indicate the direction of increase for individual variables on each PCA axis. See Table 1 for site codes.

California roach, and Sacramento sucker with a variety of other species, at low-elevation, low-gradient sites.

The results of the NMS analyses of number (abundance) and biomass provided different but complementary information. The analysis of number highlighted the importance of tailed frog tadpoles, which might be of particular interest for biodiversity issues. The analysis of biomass highlighted the importance of brook trout, which were few in number but represented a significant biomass of potential predators in these small streams. Both viewpoints are important for managing these streams for conservation purposes, and the value of the complementary information justifies the additional effort needed to weigh organisms for calculations of biomass.

The NMS analyses also provide some information regarding annual variability of aquatic vertebrate assemblages. In general, assemblages at the same site were similar in 2004 and 2005 (Figs. 2, 3). Many of the apparent differences were related by the arbitrary choice of group- ing samples at $60 \%$ similarity. At $50 \%$ similarity, most of the apparent differences disappear. Most of the larger differences between years were related to larger catches of brook trout in 2005 compared to 2004. The 1 significant difference was at Paige-Boulder Creek. Based on visual clues (e.g., little periphyton visible outside of deep pools) we suspect that this site became intermittent for some period before we sampled. The assemblage was dominated by California roach in 2004, which likely recolonized the site from a large pool just upstream of the study reach.

The aquatic vertebrate assemblages of the Upper Clear Creek Watershed were unique for several reasons. They represent an area of geographic overlap between the fish fauna of the Central Valley of California with the amphibian fauna of the North Coast of California. In particular, the co-occurrence of riffle sculpin with Pacific giant salamander is unusual, although Pacific giant salamander commonly encounter other species of sculpin (Cottus) throughout their range. The absence 
of tailed frog tadpoles at sites with riffle sculpin is consistent with the hypothesis that predation by sculpin limits the downstream distribution of tailed frog in streams. Feminella and Hawkins (1994) hypothesized that the absence of tailed frogs from lower-elevation portions of streams that supported shorthead sculpin $(C$. confusus) was due to the frog's inability to detect sculpins using the same nonvisual cues that the frog used to detect giant salamanders (Dicamptodon spp.), cutthroat trout (Oncorhynchus clarki), and brook trout.

Another notable characteristic of the aquatic assemblages was the absence of large percentages of exotic species. In many areas of California, exotic fishes compose a large percentage of the fish assemblage, especially when a reservoir is present to act as a source and refuge for exotic fishes (Moyle 2002, Brown and Moyle 2005). Similarly, the exotic bullfrog is often a dominant member of the amphibian assemblage throughout the Central Valley (Moyle 1973). Another unusual feature is the presence of a landlocked population of lamprey. The lamprey that we captured was most likely Pacific lamprey (Lampetra tridentata), which had been trapped by the construction of Whiskeytown Reservoir. The Pacific lamprey is typically an anadromous species, but landlocked populations are known from other areas of California (Moyle 2002). However, there are other possible explanations. The lamprey population may have been transported from the Trinity River system to Whiskeytown Reservoir through a diversion tunnel that moved water from Trinity Lake in the Trinity River watershed to Whiskeytown Reservoir. The most likely species in this scenario is Klamath lamprey (Lampetra similis), which is not anadromous.

The 4 habitat variables that are correlated with the distribution of species-gradient, discharge, substrate, and elevation-capture the major habitat gradients present in the study streams. The PCA results (Fig. 4) showed that all of the habitat variables which we measured, except substrate and riparian shade, were associated with 1 of these major gradients. Substrate was an important variable associated with aquatic vertebrate assemblages in some of the BV-STEP models and constituted the 3rd PCA axis, indicating that there was sufficient variability in substrate across sites to affect species composition independently of the other habitat variables. The reason for the lack of association of riparian shade with aquatic vertebrates is unknown.

Gradient, discharge, substrate, and elevation are common correlates of fish-assemblage organization around the world. In California, the native fishes could be organized into assemblages that were correlated to gradients in these variables (Moyle 2002); however, these assemblages have been disrupted by human activities and invasions of exotic fishes (Moyle 2002, Brown and Moyle 2005). Based on these previous studies, we expected the upper reaches of streams to be dominated by trout and the lower reaches to be dominated by native minnows, suckers, and at least small numbers of invasive species. The upper reaches were dominated by rainbow trout, but the native minnows, Sacramento pikeminnow and hardhead, and the native Sacramento sucker were not particularly abundant in the lower reaches. Especially notable was the absence of adults of these species. Both spring (June) and fall (September, October) snorkel surveys of our study reaches confirmed the absence of large adult fish of these species (unpublished data). These observations suggest that the mainstem Clear Creek is primarily utilized as a spawning and rearing stream by these species, as has been observed for seasonal tributaries of the Sacramento River (Villa 1985). Presumably, the adults return to the reservoir after the spring spawning season, generally MarchMay (Moyle 2002), which would account for the presence of juveniles and absence of adults in our snorkel surveys.

The low numbers of exotic fishes was somewhat unexpected. A wide variety of species has been introduced into Whiskeytown Reservoir to provide sportfishing opportunities including largemouth bass, smallmouth bass (Micropterus dolomieu), spotted bass (Micropterus punctulatus), kokanee (landlocked sockeye salmon, Oncorhynchus nerka), bluegill (Lepomis macrochirus), black crappie (Pomoxis nigromaculatus), brown trout (Salmo trutta), brook trout, channel catfish (Ictalurus punctatus), brown bullhead (Ameiurus nebulosus), and green sunfish (Lepomis cyanellus). All of these species except kokanee and black crappie are well established in the streams and rivers of the Central Valley both upstream and downstream of reservoirs (Brown 2000, May and 
Brown 2002, Moyle 2002, Brown and Moyle 2005). Although rainbow trout is native to the drainage, there is the possibility that its range has been extended upstream as a result of plantings for recreational fishing as has occurred in other areas of California (Moyle 2002). This seems most likely at the upper sites on Brandy, Boulder, and Crystal creeks where there are numerous barriers to fish movement between the upper and lower sites (i.e., waterfalls).

The success or failure of exotic species in a watershed may be associated with a number of factors (Marchetti et al. 2004). Marchetti et al. (2004) indicate that species spread is best predicted using measures of propagule pressure and physiological tolerance (i.e., the fit of a species' ecological requirements with the available habitat). Because the species are already established in the reservoir, which serves as a continual source of propagules, it seems likely that the streams are not providing appropriate habitat for the exotic species in the watershed. Recent studies suggest that flow regime may be an important factor that determines the success of invasive species in California streams (Strange et al. 1993, Marchetti and Moyle 2001, Brown and Ford 2002), although not in all cases (Moyle et al. 2003). The absence of brown trout and brook trout may result from flow regime. In contrast to the rainbow trout, which spawns in the spring, brook and brown trout spawn in the fall and their eggs remain in the gravel through the early winter (Moyle 2002). The Clear Creek watershed receives most of its precipitation as rain, so flows are very flashy. Studies in Sierra Nevada streams have shown that this flow regime favors rainbow trout over brown trout (Strange et al. 1993) because fall and winter storms scour the eggs and alevins of the fall-spawning salmonids. We suspect that the adult brook trout that we captured were planted adults that had matured and moved into the lower reaches of streams to spawn. Because we never captured any young brook trout, we believe that these spawning attempts were unsuccessful.

The absence of the exotic warmwater species, including the basses, sunfishes, and catfishes, is likely due to a combination of habitat, flow, and water temperature. Unfortunately, we only have good data for habitat. Although our measured gradients on Clear Creek were relatively low $(<1 \%)$, our sample reaches and other reaches just above the reservoir include high-gradient riffles that likely serve as physical barriers to upstream dispersal. The substrate of all the streams are dominated by coarse substrates (gravels or larger; Table 1) that are not conducive to spawning by these nest-building species. Additional continuous monitoring of stream discharge and water temperature might provide additional data to explain the dominance of native fishes.

The vertebrate aquatic assemblages of the Upper Clear Creek Watershed represent a unique combination of Central Valley and North Coast faunas. Although the component species of the combined assemblage are not particularly rare, the combination represents another manifestation of the unique geology, physiography, and ecology of the Klamath-Siskyou Ecoregion. Fortunately, a large portion of the land in the area is in federal ownership, which would presumably simplify the management of these streams and their watersheds. Human activities, such as dams, diversions, or changes in land-use, especially in the upper parts of the watersheds, should be carefully evaluated to determine if they will alter stream conditions to favor invasion of exotic species. Assuming that the present condition of the streams can be maintained or even improved, prevention of new invasions of exotic species into the region could be an appropriate management goal. Continued monitoring of the streams would be useful for detecting new invasions or habitat changes that might favor exotic species. The present rarity of exotic species is no guarantee that exotics will remain rare. For example, redeye bass (Micropterus coosae) invaded the lower reaches of the Cosumnes River, the last large undammed stream in the Central Valley, resulting in decline of native fishes and disruption of assemblage species composition (Moyle et al. 2003). Reversing the negative effects of such invasions are difficult and expensive, if even possible.

\section{ACKNOWLEDGMENTS}

We thank the personnel of Whiskeytown National Recreation Area, especially Jennifer Gibson and Windy Bunn, for help in all phases of the study. We also thank everyone who reviewed early versions of the manuscript and provided many comments that substantially improved the final article. 


\section{Literature Cited}

Beebee, T.J.C., AND R.A. Griffiths. 2005. The amphibian decline crisis: a watershed for conservation biology? Biological Conservation 125:271-285.

BIEK, D. 1988. Flora of the Whiskeytown National Recreation Area, Shasta County, California. Whiskeytown National Recreation Area, Natural Resource Management, Redding, CA.

BRown, L.R. 2000. Fish communities and their associations with environmental variables, Lower San Joaquin River Drainage, California. Environmental Biology of Fishes 57:251-269.

BRown, L.R., AND T.J. Ford. 2002. Effects of flow on the fish communities of a regulated California river: implications for managing native fishes. River Research and Applications 18:331-342.

Brown, L.R., AND P.B. Moyle. 2005. Native fish communities of the Sacramento-San Joaquin watershed, California: a history of decline. Pages 75-98 in F. Rinne, R. Hughes, and R. Calamusso, editors, Fish communities of large rivers of the United States. American Fisheries Society, Bethesda, MD.

Bruton, M.N. 1995. Have fishes had their chips? The dilemma of threatened fishes. Environmental Biology of Fishes 43:1-27.

BurY, R.B., and C.A. Pearl. 1999. Klamath-Siskiyou herptofauna: biogeographic patterns and conservation strategies. Natural Areas Journal 19:341-350.

ClaRKE, K.R., AND R.M. WARWICK. 2001. Change in marine communities: an approach to statistical analysis and interpretation. 2nd edition. Primer-E, Plymouth, U.K.

Dellasala, D.A., S.B. Reid, T.J. Frest, J.R. Strittholt, AND D.M. Olson. 1999. A global perspective on the biodiversity of the Klamath-Siskiyou ecoregion. Natural Areas Journal 19:300-319.

Feminella, J.W., and C.P. Hawkins. 1994. Tailed frog tadpoles differentially alter their feeding behavior in response to non-visual cues from four predators. Journal of the North American Benthological Society 13:310-320.

FitzPatrick, F.A., I.R. Waite, P.J. D’Arconte, M.R. Meador, M.A. Maupin, and M.E. Gurtz. 1998. Revised methods for characterizing stream habitat in the National Water-Quality Assessment Program. Water-Resources Investigations Report 98-4052. U.S. Geological Survey, Raleigh, NC.

Gopal, B. 2005. Does inland biodiversity have a future in Asian developing countries? Hydrobiologia 542:69-75.

Jennings, M.R., AND M.P. HaYes. 1994. Amphibian and reptile species of special concern in California. California Department of Fish and Game, Inland Fisheries Division, Sacramento.

KNAPP, R.A. 2005. Effects of nonnative fish and habitat characteristics on lentic herpetofauna in Yosemite National Park, USA. Biological Conservation 121: 265-279.

KnapP, R.A., AND K.R. Matthews. 2000. Non-native fish introductions and the decline of mountain yellowlegged frogs from within protected areas. Conservation Biology 14:428-438.

Kruskal, J.B. 1964a. Multidimensional scaling by optimizing goodness of fit to a nonmetric hypothesis. Psychometrika 29:1-27. 1964b. Nonmetric multidimensional scaling: a numerical method. Psychometrika 29:115-129.

Legendre, P., AND L. Legendre. 1998. Numerical ecology. 2nd English edition. Elsevier Scientific Publishing Company, Amsterdam, The Netherlands.

Lever, C. 1996. Naturalized fishes of the world. Academic Press, London.

Marchetti, M.P., T. Light, J. Feliciano, T. Armstrong, Z. Hogan, J. Viers, and P.B. Moyle. 2001. Homogenization of California's fish fauna through abiotic change. Pages 259-278 in J. Lockwood and M. McKinney, editors, Biotic homogenization. Kluwer Academic/Plenum Publishers.

Marchetti, M.P., J.L. Lockwood, and T. Light. 2006. Effects of urbanization on California's fish diversity: differentiation, homogenization and the influence of spatial scale. Biological Conservation 127:310-318.

Marchetti, M.P., And P.B. Moyle. 2001. Keeping alien fishes at bay: effects of flow regime and habitat structure on fish assemblages in a regulated California stream. Ecological Applications 11:75-87.

Marchetti, M.P., P.B. Moyle, and R. Levine. 2004. Alien fishes in California watersheds: characteristics of successful and failed invaders. Ecological Applications 14:587-596.

Mather, P.M. 1976. Computational methods of multivariate analysis in physical geography. J. Wiley \& Sons, Inc., London.

Matthews, K.R., K.L. Pope, H.K. Preisler, and R.A. KNAPP. 2001. Effects of non-native trout on Pacific treefrogs (Hyla regilla) in the Sierra Nevada. Copeia 2001:1130-1137.

MaY, J.T., AND L.R. BRown. 2002. Fish communities of the Sacramento River Basin: implications for conservation of native fishes in the Central Valley, California. Environmental Biology of Fishes 63:373-388.

McCune, B., And J.B. Grace. 2002. Analysis of ecological communities. MjM Software Design, Gleneden Beach, OR.

Moore, J.C. 2002. Trace metals in sediments from mineimpacted rivers: Clear Creek, California. Final Contract Report 02WRAG001, University of Montana, Missoula. 133 pp.

MoyLe, P.B. 1973. Effects of introduced bullfrogs, Rana catesbeiana, on the native frogs of the San Joaquin Valley, California. Copeia 1973:18-22.

2002. Inland fishes of California. 2nd edition. University of California Press, Berkeley.

Moyle, P.B., P.K. Crain, K. Whitener, and J.F. Mount. 2003. Alien fishes in natural streams: fish distribution, assemblage structure, and conservation in the Cosumnes River, California, USA. Environmental Biology of Fishes 67:277-288.

SaWyer, J.O., AND T. Keeler-Wolf. 1995. A manual of California vegetation. California Native Plant Society Press, Sacramento.

Strange, E.M., P.B. Moyle, and T.C. Foin. 1993. Interactions between stochastic and deterministic processes in stream fish community assembly. Environmental Biology of Fishes 36:1-15.

VILLA, N.A. 1985. Life history of the Sacramento sucker, Catostomus occidentalis, in Thomes Creek, Tehama County, California. California Fish and Game 71: 88-106. 
Welsh, H.W., Jr., K.L. Pope, and D. Boiano. 2006. Subalpine amphibian distributions related to species palatability to non-native salmonids in the Klamath mountains of northern California. Diversity and Distributions 12:298-309.

Williams, J.E., J.E. Johnson, D.A. Hendrickson, S. Contreras-Balderas, J.D. Williams, M. Navarro-
Mendoza, D.E. McAllister, and J.E. Deacon. 1989. Fishes of North America endangered, threatened, or of special concern. Fisheries 14(6):2-20.

Received 16 August 2006 Accepted 17 January 2007 